\title{
Recent Books and Journals in Public Opinion, Survey Methods, and Survey Statistics
}

Mario Callegaro*

Tags: statistics, survey methods, public opinion

\section{Survey Practice}

Vol. 7, Issue 2, 2014

Recent Books and Journals in Public Opinion, Survey Methods, and Survey Statistics

This article is an update of the April 2013 article. As the previous year, we organized the books by topics; this should help the readers to focus on their interests.

It is unlikely to list all new books in the field; we did our best scouting different resources and websites. The list is also focusing only on books published in the English language and available for purchase (as ebook or in print) at the time of this review (April 2014). Books are listed based on the relevance to the topic and no judgment is made in terms of quality of the content. We let the reader do so.

The journal section signals special issues of interest to Survey Practice readers and is organized in journal news and special issues sections.

Finally, following from last year, we have a thematic section with new books. This time the section is devoted to Big Data, given the interest in the industry.

If you want to send information for the next issue, please send it to surveyprac tice.new.books@gmail.com

\section{JOURNALS NEWS AND CALL FOR PAPERS}

The Journal of Official Statistics has a new publisher, De Gruyter.

Volume 29 and forthcoming are available via the new publisher website, while the previous volumes 1-28 are still available on the original JOS website

Political Psychology introduces Advances in Political Psychology. "Given this explosion of information and interest in the field, there is an increasing need for a venue where cumulative research findings are synthesized in a form accessible to the scholar, student, and practitioner. The Advances in Political Psychology annual series is intended to fill this need by publishing capstone papers that 
summarize and detail a systematic program of ongoing research on a given topic or theory".

Public Opinion Quarterly welcomes new editors Patricia Moy and Tom W. Smith.

Social Science Computer Review increased its frequency from 4 to 6 issues a year from 2013.

Survey Methods: Insights from the Field, issued a call for papers for a special iss ue on "Weighting: Practical Issues and 'How To' Approach". Deadline June 4, 2014.

Survey Research Methods is now indexed by the Social Sciences Citation Index (SSCI).

\section{JOURNALS SPECIAL ISSUES}

Cyberpsychology, Behavior, and Social Networking published a special issue on "Social Media as a Research Environment". Volume 16, Issue 9, 2013.

Evaluation 6 the Health Professions published a special issue on "Surveying Clinicians”. Volume 26, Issue 3, 2013.

Interacting with Computers published a special issue on "Commentary on Scale Derivation”. Volume 25, Issue 4, 2013.

The International Journal of Market Research published a special issue on “The Role of Social Media in Marketing”. Volume 55, Issue 6, 2013.

The International Journal of Social Research Methodology published a special issue on "Computational Social Science: Research Strategies, Design and Methods”. Volume 16, Issue 3, 2013.

The Journal of Internet Medical Research started classifying papers by topics called E-collection. There is an e-collection titled "Internet-based Survey \& Research Methodology” of interest for our readership.

Methodology: European Journal of Research Methods for the Behavioral E" Social Sciences published a special issue on "Cognitive Interviewing Reporting Format”. Volume 9, Issue 3, 2013.

Public Opinion Quarterly published a special issue on Election 2012, Volume 75, Issue S1, 2013.

Political Analysis published a free virtual issue on "Measurement in Political Science”. Available at: http://www.oxfordjournals.org/our_journals/polana/v irtualissue $5 . \mathrm{html}$.

Research Synthesis Methods published a special issue on "Inclusion of Non-Randomized Studies in Systematic Reviews”. Volume 4, Issue 1, 2014. 
Sociological Methodology published a series of papers on the symposium: "Marginal Models for Categorical Data”. Volume 43, Issues 1, 2013.

Sociological Methods and Research published a special issue on "Investigating Response Errors in Surveys”. Volume 43, Issue 1, 2014.

Statistical Journal of the IAOS: Journal of the International Association for Official Statistics published a special issue on "Getting Our Message Across" Volume 29, Issue 3, 2013.

\section{PUBLIC OPINION BOOKS}

Clawson, R.A. and Z.M. Oxley. 2013. Public opinion: democratic ideals, democratic practice (2nd ed.). CQ Press, Los Angeles, CA.

Dalton, R.J. 2013. Citizen politics: public opinion and political parties in advanced industrial democracies. CQ Press, Los Angeles, CA.

Denton, R.E. (Ed.). 2013. The 2012 presidential campaign. A communication perspective. Rowman \& Littlefield, Lanham, MD

Donsbach, W., C.T. Salmon, and Y. Tsfati. (Eds.). 2014. The spiral of silence: new perspectives on communication and public opinion. Routledge, New York.

Lodge, M. and C.S. Taber. 2013. The rationalizing voter. Cambridge University Press, Cambridge.

McCombs, M. 2014. Setting the agenda: mass media and public opinion (2nd ed.). Polity, Cambridge.

Springer, M.J. 2014. How the states shaped the nation. American electoral institutions and voter turnout, 1920-2000. Chicago, IL.

\section{SURVEY METHODS BOOKS}

Blair, J.E., R.F. Czaja and E.A. Blair. 2013. Designing surveys: a guide to decisions and procedures (3rd ed.). Sage, Chichester.

Brace, I. 2013. Questionnaire design: how to plan, structure and write survey material for effective market research (3rd ed.). Kogan Page, London.

Callegaro, M., R.P. Baker, J. Bethlehem, A.S. GÃ Gritz, J.A. Krosnick and P.J. Lavrakas. (Eds.). 2014. Online panel research: a data quality perspective. Wiley, Chichester.

Chaudhuri, A. and T. Christofides. 2014. Indirect questioning in sample surveys. Springer, Berlin.

De Vaus, D. 2013. Surveys in social research (6th ed.). Routledge, New York.

Font, J. and M. MÃ@ndez. (Eds.). 2013. Surveying ethnic minorities and immigrant populations. Methodological challenges and research strategies. 
Amsterdam University Press, Amsterdam.

Fowler, F.J. 2014. Survey research methods (5thed.). Sage, Thousand Oaks, CA. Hill, C.H., E. Dean and J. Murphy. (Eds.). 2013. Social media, sociality, and survey research. Wiley, Hoboken, NJ.

Hoffmeyer-Zlotnik, J.H.P. and U. Warner. 2014. Harmonising demographic and socio-economic variables for cross-national comparative survey research. Springer, Berlin.

Huddy, L., D.O. Sears and J.S. Levy. (Eds.). 2013. The Oxford handbook of political psychology (2nd ed.). Oxford University Press, Oxford.

Kellstedt, P. and G. Whitten. 2013. The fundamentals of political science research (2nd ed.). Cambridge: Cambridge University Press.

Kreuter, F. (Ed.). 2013. Improving surveys with paradata: analytic uses of process information. Wiley, Hoboken, NJ.

Nardi, P. 2013. Doing survey research. A guide to quantitative methods (3rd ed.). Paradigm, Boulder, CO.

Picardi, C.A. and K.D. Masick. 2014. Research methods: designing and conducting research with a real-world focus. Sage, Thousand Oaks, CA.

Poynter, R. and S. York. (Eds.). 2013. Answers to contemporary market research questions. Esomar, Amsterdam.

Reis, H.T. and C.M. Judd. (Eds.). 2014. Handbook of research methods in social and personality psychology (2nd ed.). Cambridge University Press, Cambridge.

Rutkowski, L., M. von Davier and D. Rutkowski. 2014. Handbook of international large-scale assessment: background, technical issues, and methods of data analysis. CRC Press, Boca Raton, FL.

Saßenroth, D. 2013. The impact of personality on participation decisions in surveys. A contribution to the discussion on unit nonresponse. Springer, Berlin.

Saris, W.E. and I.N. Gallhofer. 2014. Design, evaluation, and analysis of questionnaires for survey research (2nd ed.). Wiley, Chichester.

Shum, D., J. O’Gorman, B. Myors and P. Creed. (Eds.). 2013. Psychological testing and assessment (2nd ed.). Oxford University Press, Oxford.

Snijkers, G., G. Haraldsen, J. Jones and D.K. Willimack. (Eds.) 2013. Designing and conducting business surveys. Wiley, Hoboken, NJ.

Stone, A.A. and C. Mackie. (Eds.). 2013. Subjective well-being: measuring bappiness, suffering, and other dimensions of experience. Panel on measuring subjective well-being in a policy-relevant framework. National Academies 
Press, Washington, DC.

Teele, D.L. (Ed.). 2014. Field experiments and their critics: essays on the uses and abuses of experimentation in the social sciences. Yale University Press, New Haven, CT.

Vis, F. and M. Thelwall. 2014. Researching social media. Sage, London.

Winker, P., N. Menold and R. Porst. (Eds.). 2013. Interviewers' deviations in surveys: impact, reasons, detection and prevention. Peter Lang, Berlin.

Zmud, J., M. Lee-Gosselin J.A. Carrasco and M. Munizaga. (Eds.) 2013. Transport survey methods: best practice for decision. Emerald, Bingley, UK.

\section{SURVEY STATISTICS BOOKS}

Adams, K.A. and E.M. Kung. 2014. Research methods, statistics, and applications. Sage, Los Angeles, CA.

Allison, P.D. 2013. Event history and survival analysis. (2nd ed.). Sage, Los Angeles, CA.

Andreß, H.-J., K. Golsch and A.W. Schmidt. 2013. Applied panel data analysis for economic and social surveys. Springer, Berlin.

Carsey, T.M. and J.J. Harden. 2014. Monte Carlo simulation and resampling methods for social science. Sage, Los Angeles, CA.

Gelman, A., J.B. Carlin, H.S. Stern, D.B. Dunson, A. Vehtari and D.B. Robin. 2013. Bayesian data analysis (3rd ed.). CRC Press, Boca Raton, FL.

Gerbin, D.W. 2013. $R$ data analysis without programming. Routledge, New York.

Harlow, L.M. 2013. The essence of multivariate thinking. Basic themes and methods (2nd ed.). Routledge, New York.

Jose, P.E. 2013. Doing statistical mediation and moderation. Guilford, New York.

Kim, J.K. and J. Shao. 2013. Statistical methods for handling incomplete data. CRC Press, Boca Raton, FL.

Kraska-Miller, M. 2014. Nonparametric statistics for social and behavioral sciences. CRC Press, Boca Raton, FL.

Little, T.D. 2013. Longitudinal structural equation modeling. Guilford, New York.

Little, T.D. (Ed.). 2013. The Oxford handbook of quantitative methods in psychology (Vol. 2). Statistical analysis. Oxford University Press, Oxford. 
Marchant-Shapiro, T. 2014. Statistics for political analysis: understanding the numbers. CQ Press, Los Angeles, CA.

McNabb, D.E. 2014. Nonsampling error in social surveys. Sage, Thousand Oaks, CA.

Rao, V.R. 2014. Applied conjoint analysis. Springer, Berlin.

Rayn, T.P. 2013. Sample size determination and power. Wiley, Hoboken, NJ.

Schmidt, F.L. and J.E. Hunter. 2014. Methods of meta-analysis: correcting error and bias in research findings (3rd ed.). Sage, Los Angeles, CA.

Seber, G.A.F. 2013. Statistical models for proportions and probabilities. Springer, Berlin.

Smithson, M. and E.C. Merkle. (2013). Generalized linear models for categorical and continuous limited dependent variables. CRC Press, Boca Raton, FL.

Spenser, N.H. 2013. Essentials of multivariate data analysis. CRC Press, Boca Raton, FL.

Tian, G.Y. and M.L. Tang. 2013. Incomplete categorical data design. Non-randomized response techniques for sensitive questions in surveys. CRC Press, Boca Raton, FL.

Valliant, R., J. Dever and F. Kreuter. 2013. Practical tools for designing and weighting survey samples. Springer, New York.

Wakefield, J. 2013. Bayesian and frequentist regression methods. Springer, Berlin.

Walgreen, A. and B. Walgreen. 2014. Register-based statistics: statistical methods for administrative data (2nd ed.). Wiley, Chichester.

Xiaofeng, S.L. 2013. Statistical power analysis for the social and behavioral sciences. Basic and advanced techniques. Routledge, New York.

\section{BIG DATA BOOKS}

Bloem, J., M. van Doorn, S. Duivestein, T. van Manen, E. van Ommeren and S. Sachdeva. 2013. No more secrets with big data analytics. Sogeti, Groningen.

Fung, K. 2013. Numbersense: How to use big data to your advantage. McGraw-Hill, New York.

Mayer-Schönberger, V. and K. Cukier. 2013. Big data. A revolution that will transform how we live, work, and think. Houghton Mifflin Harcourt, New York.

Mayer-Schönberger, V. and K. Cukier. 2014. Learning with big data. The 
future of education (eBook only). Houghton Mifflin Harcourt, New York. 